\title{
REKONSTRUKSI IDENTITAS KE-“TIONGHOA"-AN DALAM FILM INDIE PASCA-SUHARTO
}

\author{
Umilia Rokhani $^{1}$, Aprinus Salam ${ }^{2}$, Ida Rochani-Adi ${ }^{3}$ \\ Program Studi Ilmu-Ilmu Humaniora, Fakultas Ilmu Budaya, Universitas Gadjah Mada \\ Jalan Nusantara No. 1, Bulaksumur, Catur Tunggal, Yogyakarta 55281 \\ No.HP.:082221953779,_E-mail: umilia_erha@yahoo.co.id
}

\begin{abstract}
Abstrak
Ke-“tionghoa"-an senantiasa menjadi hal yang dipermasalahkan di Indonesia. Hal ini mengacu pada identitas ke-"tionghoa"-an yang selalu diformulasikan oleh masyarakat Indonesia, baik oleh masyarakat Tionghoa itu sendiri maupun masyarakat non-Tionghoa. Upaya formulasi tersebut dimunculkan melalui berbagai wacana yang muncul baik perdebatan publik maupun berbagai karya mengenai kehidupan masyarakat Tionghoa di Indonesia seperti dalam film. Metode yang dipakai mempergunakan pendekatan konstruktivisme sosial. Dalam hal ini, makna-makna subjektif dikaji atas pengalaman-pengalaman kehidupan masyarakat Tionghoa di Indonesia melalui representasi film indie. Representasi tersebut dikaji tidak hanya melalui makna karya semata, tetapi juga mempertimbangkan unsur sejarah sebagai salah satu penentu alat produksi dan reproduksi. Hal ini dilakukan dengan tujuan agar diperoleh gambaran latar belakang yang kompleks mengenai kondisi historikal dan kultural kehidupan masyarakat Tionghoa di Indonesia. Gambaran yang kompleks tersebut akan membantu dalam menafsirkan makna-makna yang terkandung dalam karya film indie sebagai suatu hasil produksi dan reproduksi dari gambaran kehidupan masyarakat Tionghoa sebenarnya. Identitas masyarakat Tionghoa di Indonesia terbentuk baik dari pandangan eksternal maupun internal, sudut pandang formal maupun informal. Sudut pandang eksternal dilihat dari sisi luar masyarakat Tionghoa, sedangkan sudut pandang internal merupakan sudut pandang masyarakat Tionghoa membentuk jati dirinya sendiri. Identitas yang dibentuk secara formal terkait dengan peraturan perundangan yang diberlakukan di Indonesia sedangkan secara informal merupakan identitas yang dikembangkan melalui kolaborasi budaya bersifat mana suka (arbitrerness) yang pada akhirnya membentuk identitas baru yang tumbuh dari konteks ruang-antara masyarakat Tionghoa di Indonesia.
\end{abstract}

Kata Kunci: ke-“tionghoa"-an, film indie, identitas

\begin{abstract}
The Reconstruction of Tionghoaness Identity in Indonesian Indie Movies in the Era of PostSuharto. 'Being a Chinese' has always been an issue in Indonesia. It refers to the identities of 'being a Chinese' that were formulated by Indonesian people, both by the half-Chinese Indonesians and non half-Chinese Indonesians. The efforts in formulating those identities were mediated by various discourses found in public debates and works of arts represented the Chinese society life in Indonesia, such as in films. In this research, the social constructivism approach was applied. The experiences in life traversed by the Chinese society in Indonesia depicted in indie movies were studied to get the subjective meanings. The representations were not scrutinized merely from the meaning, but also by considering the historical aspects as, among others, the determinant factor of the means of production and reproduction. It was carried out to get the full picture of complicated background about the historical and cultural conditions of the Chinese people in Indonesia. The complicated depiction will be very beneficial in interpreting the meanings of the indie movies as a result of production and reproduction of the real life experienced by the Chinese society. The identity of Chinese people in Indonesia was shaped by the internal and external perspectives, by the formal and non formal point of
\end{abstract}


views. The external point of view was the one given by the non Chinese people, whereas the internal was how the Chinese view themselves. The formally built identity was related to the laws applied in Indonesia. Arbitrary cultural collaborations informally developed the new Chinese identity that grew from the spatial contexts between the Chinese people in Indonesia.

Keywords: tionghoaness, indie film, identity

\section{PENDAHULUAN}

Kehidupan masyarakat Tionghoa di Indonesia senantiasa dipermasalahkan keberadaannya sejak zaman kolonial hingga masa kini. Kondisi ini muncul dalam representasi berbagai karya bertema Tionghoa, salah satunya dari karya film. Pada era Suharto, karya film bertema Tionghoa ini mengalami keterbungkaman. Keterbungkaman karya film bertema Tionghoa tersebut sejalan dengan pernyataan Heryanto (1997:26) bahwa tema ke"tionghoa"-anhanyabersifatpelengkapterhadap tema-tema utama lainnya. Selain itu, film-film yang bertema ke-“tionghoa"-an menjadi sarana propaganda untuk berbagai tujuan politis. Oleh karena itu, penggambaran stereotip masyarakat Tionghoa di Indonesia tidak mengalami perubahan yang signifikan. Masyarakat Tionghoa masih banyak digambarkan dengan pencitraan negatif ataupun digambarkan dalam posisi yang selalu dipermasalahkan ke-“tionghoa"-annya. Hal ini sejalan dengan pemaparan Allen (2003:399) mengenai terjadinya pelanggengan stereotip terhadap etnis Tionghoa dalam sastra Indonesia pascaSuharto. Representasi kehidupan masyarakat Tionghoa di Indonesia menjadi sebuah refleksi. Refleksi tersebut menunjukkan perspektif sineas Indonesia yang memiliki maksud tertentu melalui narasi yang diwacanakan mengenai masyarakat Tionghoa di Indonesia. Dalam hal ini, bidikan pengarang ataupun sineas Indonesia untuk mengungkap lebih dalam permasalahan kehidupan masyarakat Tionghoa di Indonesia cenderung memaparkan wacana bahwa masalah ke-"tionghoa"-an merupakan hal yang terus-menerus dipermasalahkan di Indonesia, baik oleh masyarakat non-Tionghoa maupun masyarakat Tionghoa itu sendiri. Kisah memberikan makna dan kebijaksanaan pada kehidupan manusia dan berfungsi sebagai 'tanda-tanda narasi' yang mewakili eksistensi yang memiliki tujuan tertentu(Danesi, 2010:54). Bahkan lebih lanjut, disebutkan bahwa kisah tersebut juga menjadi penggambaran yang menguatkan ironi tentang adanya kesalahan sistem selama ini (Danesi, 2010:151-152). Ironi dalam hal ini berupa penyikapan dan pemosisian Tionghoa di Indonesia yang selalu diambangkan dengan dipertegas melalui berbagai kebijakan pemerintahan yang berlaku. Pengambangan tersebut berupa pengindonesiaan orang Tionghoa di Indonesia sekaligus menegas-negaskan ke-“tionghoa"-an mereka. Hal tersebut yang banyak dinarasikan dalam karya-karya bertema Tionghoa.

Dalam hal ini, kajian ke-"tionghoa"-an tidak dapat dilepaskan dari konteks historikal perjalanan kehidupan masyarakat Tionghoa di Indonesia. Lini kehidupan masyarakat Tionghoa di Indonesia tidak dapat dilepaskan dari pemosisian Tionghoa di Indonesia secara politis sejak masa kolonial Belanda. Pada masa penjajahan Belanda, pemberlakuan politik segregasi membagi masyarakat menjadi tiga golongan, yaitu: pertama, golongan bangsa Eropa (Belanda), kedua, golongan Timur Asing yang diisi oleh orang-orang Tionghoa 
dan Arab, dan ketiga,golongan pribumi (Suryadinata, 1984:4; Mahfud, 2013:53). Pemosisian Tionghoa di atas golongan pribumi menumbuhkan perasaan tidak senang secara global terhadap masyarakat Tionghoa.

Pasca-Suharto pada tahun 1998, di televisi mulai muncul kembali tema yang mengangkat kehidupan etnis Tionghoa di Indonesia seperti Lo Fen Koei (RCTI, 2001), dan serial drama Cinta Terhalang Tembok (2002) (Allen, 2003:389). Selain itu, menurut Setijadi (2013:65) daftar panjang film bertema Tionghoa pasca-Suharto lebih banyak muncul pada filmfilm berlabel indie. Tercatat sebanyak tujuh belas buah judul film bertema Tionghoa diproduksi secara indie. Komunitas pemroduksi film indie ini baru bermunculan di akhir Orde Baru dan awal Reformasi (Junaedi, www.umy.ac.id, diakses pada 3 Oktober 2013, pukul 19.07 WIB).

Film indie (independen) adalah film pendek yang diproduksi dengan mempergunakan peralatan kamera video yang sederhana serta dengan proses yang sederhana. Film independen menunjukkan ciri film menjadi milik publik. Semua orang bisa merasa dan mampu membuat serta mengapresiasikan film, film milik masyarakat. Bahkan, masyarakat bisa menamai film-film yang dibuat dengan nama-nama yang baru seperti film aspirasi, expanded cinema, film eksperimental, dan lain sebagainya. Di Indonesia, film independen mempergunakan penyebutan nama-nama yang bervariatif seperti film pendek, film mini, film alternatif, film indie, film individual, film personal, Sinema Gerilya, dan lain sebagainya (Prakoso, 2006:175-176).

Film indie dapat mewakili pembuatnya sebagai film-film atau karya yang dapat mencerminkan sikap pembuatnya secara utuh. Film indie membawa pandangan pembuatnya dan film yang menjadi produksi teknologi dan seni yang berarti pengetahuan dan visi yang diterapkan menjadi sesuatu yang universal dengan bahasa simbol dalam media berteknologi tinggi (Prakoso, 2006:57-58). Oleh karena itu, film bertema Tionghoa tersebut perlu dilihat sebagai sebuah karya seni yang membawa idealisme dan pandangan pembuatnya. Selain itu, Setijadi (2013:70-71) memaparkan bahwa film independen dibuat bukan untuk tujuan komersial yang mengikuti selera pasar, melainkan untuk tujuan mengikuti kompetisi festival film. Pembedaan ini menjadi tolok ukur pembedaan film dominan atau mainstream film dengan film eksperimental (avant garde) (Bordwell \& Kristin Thompson, 2001:128-138). Mainstream film mengacu pada popular film, sedangkan film eksperimental mengarah pada art film. Art film mengacu pada kategori elitism. Elitism berkomitmen dengan kondisi sosial ekonomi sebagai otoritas standar bingkai kerja dan menolak demokrasi anarki. Hal ini terjadi seperti aliran vanguard yang masuk ke ranah konflik dengan perkembangan akademik yaitu konflik yang menggerakkan unsur-unsur ideologi yang radikal dan liberal yang mengsubordinatkan kelompok dan kelas (Eagleton, 1978:14). Umumnya, film indie masuk dalam jajaran film eksperimental. Film eksperimental lebih menekankan pada ekspresi pengalaman personal atau sudut pandang pada cara yang terlihat lebih eksentrik dalam konteks mainstream. Gambar yang dimunculkan mungkin diambil sebagai fragmen keaktualan yang dapat digerakkan untuk berbagai tujuan yang berbeda. Selain itu, eksperimental juga mempergunakan tahapan untuk mengekspresikan perbedaan perasaan atau gagasan.

Film eksperimental terkadang mempergunakan bentuk naratif, abstrak 
dan asosiasional. Bentuk abstrak pada film eksperimental ditunjukkan melalui tema dan variasi. Istilah ini biasanya muncul melalui musik berupa melodi atau tipe motif lainnya yang diperdengarkan, dan kemudian rangkaian versi dari melodi sama yang mengikuti itu sering muncul dengan perbedaan kunci dan rythm yang ekstrim sehingga melodi aslinya menjadi sulit untuk dikenali. Sementara itu, bentuk asosiasional digambarkan dengan mempergunakan rangkaian transisi puitik untuk menciptakan bentuk asosiasional. Sistem asosiasional mengarahkan pada kualitas dan konsep ekspresi yang mengelompokkan gambar bukan pada koneksi logis. Namun kenyataannya, gambar dan suara yang terletak sejajarmendorong untukmencarikoneksiberupa asosiasi yang mengikat menjadi satu makna. Film populer akan lebih mempertimbangkan selera pasar untuk mengambil keuntungan dari produksi film tersebut. Sementara itu, film sebagai art lebih menekankan pada visi otentik atau ekspektasi penciptanya terhadap materi hasil produksi filmnya (Andrew, 1984:12).

Tujuan dari penulisan ini untuk melihat konstruksi identitas ke-“tionghoa"-an melalui bingkai wacana film indie Indonesia pascaSuharto melalui pijakan konteks sosio-politik. Rekonstruksi identitas yang dipaparkan melalui film dengan bahasa visual akan memberikan gambaran yang lebih konkret mengenai bentuk pemikiran, akar permasalahan maupun dampak yang ditimbulkan atas berbagai permasalahan identitas ke-“tionghoa"-an.

\section{METODE PENELITIAN}

Pendekatan dalam penelitian ini berdasar pada konstruktivisme sosial. Konstruktivisme sosial meneguhkan asumsi bahwa manusia senantiasa terlibat dengan dunia mereka dan berusaha memahami berdasarkan perspektif historis dan sosialnya sendiri (Creswell, 2012:12). Hal ini sejalan dengan teori materialis bahwa sastra menjadi bagian bangunan yang bukan refleksi pasif semata. Sastra turut bekerja pada penentuan unsur sejarah yaitu pada produksi dan reproduksi dalam kehidupan nyata. Oleh karena itu, teori materialis menuntut seni, dalam hal ini film, dapat menjadi unsur aktif serupa perubahan (Eagleton, 2006:4-5).

Dalam hal ini, peneliti berupaya mengkaji makna-makna subjektif atas pengalaman-pengalaman kehidupan masyarakat Tionghoa di Indonesia melalui interpretasi film indie. Interpretasi tersebut dikaji bukan hanya melalui makna karya semata, tetapi juga mempertimbangkan unsur sejarah sebagai salah satu penentu alat produksi dan reproduksi. Schleiermacher menyatakan bahwa terdapat faktor-faktor yang ikut membentuk teks yaitu gramatik dan person pembuatnya. Interpretasi gramatis akan membawa penafsir pada interpretasi historis. Dalam hal ini teks ditempatkan dalam konteks. Dengan mengembalikan makna pada konteks historisnya, keanekaragaman interpretasi akan menemukan objektivitas makna (Hardiman, 2015:57-58).

Pembatasan pemilihan karya film indie pasca-Suharto tidak diikuti pembatasan terhadap kajian historikal hanya pada masa pasca-Suharto. Kajian historikal direntang secara lebih luas dari masa kolonial hingga pasca-Suharto. Hal ini dilakukan dengan tujuan agar diperoleh gambaran latar belakang yang kompleks mengenai kondisi historikal dan kultural kehidupan masyarakat Tionghoa di Indonesia. Gambaran yang kompleks tersebut akan membantu dalam menafsirkan makna- 
makna yang terkandung dalam karya film indie sebagai suatu hasil produksi dan reproduksi dari gambaran kehidupan masyarakat Tionghoa sebenarnya.

\section{KONSEP IDENTITAS}

Film merepresentasikan gagasangagasan terhadap objek melalui simbolsimbol. Gagasan tersebut mewacanakan interaksi simbolik objek selaku diri. Interaksi tersebut membangun identitas diri objek. Identitas merupakan seperangkat makna yang menentukan seseorang tersebut memiliki peran tertentu dalam masyarakat, anggota dari suatu kelompok tertentu atau klaim karakteristik tertentu yang mengidentifikasikannya sebagai pribadi yang unik (Burke \& Stets, 2009:3). Dalam hal ini individu berada dalam konteks struktur sosial. Masyarakat sebagai struktur sosial diciptakan oleh tindakan-tindakan individu-individu, meski diakui bahwa tindakan tersebut diproduksi dalam konteks struktur sosial yang dibuat dan dipengaruhi oleh konteks ini. Jadi terdapat pengaruh timbal balik antara karakteristik individual dan karakteristik masyarakat. Dalam hal ini, individu merupakan agen yang memiliki peran dan tujuan sehingga tindakan dan interaksi yang dilakukan berdasarkan peran dan tujuan tersebut. Peran dalam hal ini terikat dalam struktur, perilaku dan harapan. Agen dalam hal ini merupakan entitas tindakan. Dalam penelitian ini, para sineas merupakan individu yang menjadi agen melalui karya-karyanya.

Individu terkait dengan masyarakat karena adanya interaksi struktural simbolik. Interaksi struktural simbolik merupakan seperangkat ide-ide tentang sifat individu dan hubungan antara individu dengan masyarakat. Hubungan individu dengan masyarakat menunjukkan adanya relasi antara satu individu dengan individu lainnya. Respon atas diri (self) sebagai objek simbolis berasal dari sudut pandang Liyan (the other) yang berinteraksi dengan diri dan hal tersebut berpengaruh pada respon diri kepada respon Liyan. Jadi secara paradoksal, diri (self) muncul sebagai objek pembeda. Pada waktu yang sama terjadi penyatu perspektif diri dan Liyan dan penyatuan tersebut merupakan implikasi dari berbagai makna dari objek dan simbol yang direspon dalam interaksi sosial. Hal itu berpengaruh pada fakta bahwa dalam penggunaan bahasa, baik diri maupun Liyan mengomunikasikan makna yang sama untuk diri (self) sekaligus Liyan (the other) itu sendiri.

Berdasarkan hubungan diri dan Liyan tersebut diketahui bahwa terdapat hubungan yang relasional dalam proses pengidentifikasian baik diri maupun Liyan. Diri dapat diidentifikasi saat diri meliyankan orang lain. Melalui relasi ini, Bhabha pun menegaskan bahwa tidak ada suatu budaya yang benar-benar murni. Selain itu, Bhabha juga menyangkal bahwa budaya tersebut hanya terpolarisasi pada Barat dan Timur. Bhabha (1994:1-2) memaparkan mengenai konsepsi ruang-antara. Konsepsi ini menyediakan tempat untuk memperluas strategi kedirian - baik individu maupun komunal - yang menghasilkan tanda-tanda identitas baru, dan jenis-jenis kolaborasi yang inovatif sekaligus persaingan dalam upaya untuk mendefinisikan identitas masyarakat itu sendiri. Konsepsi tersebut membawa pada penegosiasian budaya. Ruang-antara tersebut mengkontaminasi narasi yang mapan dan sudut pandang yang dominan.

Hal tersebut memunculkan celah - saling tumpang tindih dan pergeseran wilayah perbedaan - untuk menegosiasikan intersubjektivitas, pengalaman kolektif tentang 
kebangsaan, kepentingan komunitas atau nilainilai budaya. Representasi terhadap perbedaan tidak harus dilihat secara tergesa sebagai refleksi ciri etnis atau budaya yang terberi yang diatur dalam tradisi yang tidak bisa diubah lagi. Dari perspektif minoritas, artikulasi sosial atas sebuah perbedaan adalah sebuah negosiasi yang kompleks dan terus menerus yang berupaya untuk mewujudkan hibriditas budaya yang muncul dalam setiap kesempatan transformasi historis (Bhabha, 1994:2).

Individu yang hidup dalam ruangantara tersebut hidup dalam suatu ambivalensi yang membentuknya menjadi bersifat mimikri, subjek berbeda -hampir sama, tetapi berbeda. Mimikri muncul sebagai representasi perbedaan yang berupa proses pengingkaran. Mimikri merupakan tanda dari sebuah artikulasi ganda berupa sebuah strategi perombakan, strategi peraturan dan strategi disiplin keilmuan yang kompleks, yang menyerupai Liyan seperti saat Liyan memperlihatkan kekuasaannya.

Ambivalensi mimikri tidak hanya muncul pada tataran wacana, tetapi menjadi transformasi ke dalam ketidakpastian yang pasti pada subjek kolonial sebagai kehadiran yang parsial. Dengan parsial tersebut, individu tersebut menjadi individu yang tidak utuh dan maya. Hal ini seolah-olah representasinya sangat tergantung pada peraturan penguasa pada beberapa pembatasan atau pelarangan strategis dalam wacana otoritas itu sendiri (Bhabha, 1994:88). Berdasarkan konsepsi yang dikemukakan Bhabha, Ang juga mengembangkan konsep hibriditas pada keragaman, ketidakpastian dan ambivalensi. Selain itu, hibriditas juga lebih menekankan pada kebersamaan dalam perbedaan (Ang, 2001:2-3).

\section{KE-"TIONGHOA"-AN DALAM PERMASALAHAN IDENTITAS DI INDONESIA}

Ke-"tionghoa"-an harus dilihat dari berbagai aspek kehidupan yang dapat dirunut dari sejarah kehidupan masyarakat Tionghoa di Indonesia mengenai ruang gerak dan eksistensi mereka maupun media sebagai wadah untuk memaparkan bentuk identitas ke-"tionghoa"an itu sendiri. Konsep ke-"tionghoa"-an pada mulanya bukanlah menjadi masalah yang rumit. Konsep tersebut dibentuk dan selanjutnya mengacu pada orang Tionghoa itu sendiri. Hal ini menciptakan berbagai identitas yang menekankan pada nilai cara tradisi keluarga, klan, loyalitas etnik seperti simbol-simbol kejayaan China di masa lalu. Hal-hal tersebut menopang konsep ke-“tionghoa"-an (Lohanda, 2002:15). Dengan demikian, konsep identitas yang dilekatkan orang Tionghoa pada dirinya adalah identitas secara historikal.

Namun perkembangan berikutnya konsep ke-"tionghoa"-an tidak dapat dibatasi secara jelas, mengingat ke-"tionghoa"-an tidak dapat dilepaskan dari posisi masyarakat Tionghoa yang senantiasa diambangkan melalui politik segregasi yang terbagi menjadi tiga golongan, yakni: golongan bangsa Eropa (Belanda), golongan Timur Asing yang diisi oleh orang-orang Tionghoa dan Arab, dan golongan pribumi. Dengan penggolongan kelas tersebut, Tionghoa ditempatkan pada posisi kedua setelah golongan Eropa atau penjajah yang bermukim di wilayah jajahannya dan di atas golongan pribumi (Suryadinata, 1984:4; Hoon, 2012:26; Mahfud, 2013:53).

Selain pembagian secara eksternal tersebut, dikotomi secara internal orang Tionghoa juga terbagi menjadi tiga, yaitu pertama, golongan totok yaitu golongan 
murni yang datang dari tanah leluhur dan tidak memiliki percampuran darah dengan golongan manapun, kedua, golongan peranakan yaitu golongan yang telah memiliki percampuran darah dengan penduduk asli tetapi masih membawa nilai-nilai dan pedoman hidup dari tanah leluhur sekalipun budaya setempat juga sudah mempengaruhi kehidupannya, dan ketiga, golongan peranakan yang telah memiliki percampuran darah serta tidak lagi memegang prinsip-prinsip hidup dari tanah leluhur dan sudah mengikuti adat istiadat setempat (Joesoef, 1996:18-19). Salah satu yang menjadi tolok ukur kemurnian dari pengidentikan orang Tionghoa di Indonesia dengan kehidupan dan nilai-nilai tanah leluhur adalah penguasaan bahasa ibu atau bahasa Mandarin. Lunturnya penguasaan terhadap bahasa Mandarin karena perkawinan atau interaksi dengan pribumi menyebabkan perkawinan campur antara Tionghoa dan pribumi dianggap menurunkan derajat status kelas sosial bagi orang Tionghoa berdasarkan hierarki pembagian kelas tersebut (Hoon, 2012: xxxviii-xxxix). Hal tersebut menunjukkan adanya pemetaan pemecahan kelas yang lebih kecil lagi dibandingkan pembagian hierarki pembagian kelas yang ditetapkan pada masa penjajahan Belanda di kalangan orang Tionghoa di Indonesia antara golongan totok dan golongan peranakan. Konstruksi pemecahan kelas ini dipertegas dengan perbedaan pandangan. Golongan totok merasa derajatnya lebih tinggi karena kemurnian pertalian darah, sedangkan golongan peranakan memiliki strata perekonomian yang lebih tinggi sehingga memandang golongan totok lebih rendah dari golongan mereka. Dengan demikian, konsep ke-"tionghoa"-an menjadi sulit untuk dipahami sebagai suatu identitas karena senantiasa terbelah antara "menjadi
Tionghoa" dan "menjadi tidak Tionghoa". Ke"tionghoa"-an cenderung didefinisikan dalam repetisi dengan mempergunakan perbedaan kata walau keduanya memiliki gambaran konkret, yang intinya "untuk mengidentifikasi hal yang sama" (Lohanda, 2002:14-15).

Pembagian hierarki dalam masyarakat tersebut berimplikasi pada berbagai aturan yang menyertainya, salah satunya adalah penentuan tempat tinggal (wijkenstelsel). Aturan wijkenstelsel yaitu aturan pemukiman menurut pembagian kelompok etnis. Aturan tersebut yang mengatur orang-orang Tionghoa diharuskan untuk tinggal di kantong-kantong pemukiman Tionghoa yang disebut dengan pecinan (Kustedja, 2012:110). Melalui peraturan tersebut, penerapan pajak tinggi tidak dapat dihindari oleh masyarakat Tionghoa karena masyarakat Tionghoa maupun non-Tionghoa dibedakan bukan atas atribut ke-"tionghoa"-annya melainkan lokasi pemukimannya. Pecinan itu sendiri hingga saat ini masih dapat ditemukan tersebar di berbagai wilayah Indonesia. Selain itu, orang Tionghoa diharuskan untuk memiliki surat jalan setiap kali akan melakukan perjalanan bila melebihi batas waktu yang ditetapkan (passenstelsel). Hak-hak lain yang tidak dapat diperoleh orang Tionghoa sebagai pendatang adalah kepemilikan atas tanah (Hatta, 1988:10).

Selain itu, munculnya kebijakan pemerintah kolonial terhadap pendidikan formal untuk golongan Tionghoa ini juga dipengaruhi oleh gerakan nasionalisme di daratan Tiongkok. Gerakan ini memunculkan resinifikasi atau pencinaan kembali akibat dari tumbuhnya perasaan dan identitas ke-“tionghoa"-an terutama golongan Tionghoa di luar Tiongkok daratan. Orientasi pada tanah leluhur melalui simbol-simbol kejayaan Tiongkok menempatkan 
masyarakat Tionghoa di Indonesia secara kultural terpisah dari masyarakat lainnya. Dengan demikian, ditinjau dari aspek sejarah, konsep ke"tionghoa"-an muncul sebagai bentuk pencarian identitas dalam diri masyarakat Tionghoa dengan cara mentionghoakan kembali diri mengikuti kiblat tanah leluhur. Sekalipun dalam praktiknya, penentuan suatu identitas bukanlah hal yang mudah dilakukan selaku warga diaspora yang tentu saja tidak dapat melepaskan begitu saja sebagian jati dirinya dari negara yang ditinggali atau tanah kelahiran.

Masalah kewarganegaraan masyarakat Tionghoa di Indonesia menjadi hal penting dalam perkembangan gagasan politik di Indonesia melalui pemikiran-pemikiran tokoh nasionalis Indonesia, seperti Mohammad Hatta dan Sukarno. Mohammad Hatta lebih menekankan pemikirannya pada pengakuan status Tionghoa sebagai bagian dari warga negara Indonesia dan pemfokusan pada sektor ekonomi yang melibatkan peran orang Tionghoa di Indonesia. Hatta memberikan pengakuan bahwa masyarakat Tionghoa di Indonesia sebagai bagian dari Indonesia. Selain itu, ia mendukung peran Tionghoa dalam mengangkat sektor ekonomi Indonesia dengan mengajukan saran untuk bergerak bersama pribumi Indonesia sebagai mitra kerjanya. Hatta juga menentang diskriminasi rasial dalam sektor ekonomi karena menganggap diskriminasi rasial akan menghambat bangsa Indonesia sebagai bangsa yang homogen. Selain itu, Hatta juga menyangsikan bahwa perekonomian Indonesia akan dapat berjalan tanpa campur tangan perusahaan asing. Sementara itu, Sukarno juga mengakui bahwa Tionghoa di Indonesia merupakan anggota bangsa Indonesia sebagai salahsatusukubangsa. Sukarnomenyetujuibahwa Tionghoa di Indonesia harus menghilangkan ekslusivisme dan mengedepankan asimilasi sebagai bentuk penyatuan ke dalam bangsa Indonesia (Suryadinata, 1984:26). Gagasangagasan pemikiran para tokoh nasionalis ini yang selanjutnya berbentuk sebagai benih pemikiran terhadap Program Asimilasi yang diterapkan sebagian pada masa pemerintahan Suharto.

Program asimilasi yang dicanangkan pemerintahan Suharto atas masyarakat Tionghoa diterapkan melalui berbagai aturan-aturan formal. Program Asimilasi ini bertujuan untuk membaurkan orang Tionghoa dengan warga pribumi melalui legalitas identitas yang bersifat tunggal. Melalui program tersebut, pemerintah Suharto berupaya untuk membangun ideologi nasional yang homogen di tengah masyarakatnya yang plural. Hal tersebut menyebabkan dilarangnya berbagai aktivitas politik, religi, sosial budaya maupun pendidikan untuk masyarakat Tionghoa, termasuk diskusi mengenai topik ke"tionghoa"-an di ruang publik.

Dampak aplikasi dari program tersebut, masyarakat Tionghoa tidak diperbolehkan lagi mempertahankan identitasnya yang membawa akar leluhurnya, seperti penggunaan nama Tionghoa, berbagai tradisi dan budaya yang mengandung unsur Tionghoa, bahkan hingga keyakinan religi yang harus turut dibaurkan sehingga terlepas konstruksi identitas Tionghoa dan berubah pada konstruksi identitas keindonesiaannya. Pola produksi kebijakan tersebut memaksakan suatu konstruksi bentuk sikap dan identitas masyarakat Tionghoa. Dengan adanya berbagai tuntutan atas diri dan posisi, masyarakat Tionghoa berupaya untuk bersikap pragmatis agar mempermudah dalam beradaptasi dengan situasi, kondisi dan kebijakan yang diterapkan oleh pemerintah.

Program Asimilasi tersebut diterapkan dengan mengedepankan diskriminasi rasial 
atas Tionghoa di Indonesia. Hoon (2012:5) menyebutkan bahwa selama rezim Orde Baru, semua warga negara Indonesia dengan berbagai latar belakang suku, ras, gender berada dalam identitas nasional Pancasila yang dikonstruksi secara homogen. Ideologi nasional tersebut tidak berjalan efektif untuk mengakomodir keberadaan Tionghoa di Indonesia. Program Asimilasi diterapkan dengan dukungan militer untuk membatasi dominasi sektor ekonomi oleh masyarakat Tionghoa. Dengan demikian, Program Asimilasi ini menempatkan posisi Tionghoa di Indonesia pada posisi yang serba salah. Program ini menentukan penghapusan secara total segala tanda dan penanda ke"tionghoa"-an dan memaksa peleburan diri ke dalam budaya-budaya daerah yang telah diakui sebagai budaya Indonesia melalui pembakuan aturan perundang-undangan maupun kebijakan pemerintah lainnya.

\section{REKONSTRUKSI IDENTITAS TIONGHOA DALAM REPRESENTASI FILM INDIE}

Representasi identitas Tionghoa pada beberapa film indie pasca-Suharto dibangun melalui aspek formal dan informal. Aspek formal yang muncul pada representasi tersebut muncul melalui regulasi yang diterapkan sebagai sikap politis pemerintah terhadap masyarakat Tionghoa. Aturan Keppres Kabinet No. 127/U/Kep/12/1966 mengenai kewajiban Warga Negara Indonesia dari etnis Tionghoa untuk mengadopsi nama bernada Indonesia (misalnya: Liem menjadi Halim, Lo/Loe/Liok menjadi Lukito) ditetapkan dan muncul menjadi ide penceritaan yang dikembangkan dalam film indie Sugiharti Halim (selanjutnya disingkat SH). Sementara film A Letter of Unprotected Memories (selanjutnya disingkat $A L U M$ ) diawali dengan prolog tulisan kondisi selama 33 tahun diberlakukannya peraturan Inpres No. 14/1967 tentang Agama, Kepercayaan dan Adat Istiadat Tionghoa. Undang-undang ini melarang perayaan Hari Raya Tionghoa, penggunaan bahasa Mandarin, dan adat istiadat Tionghoa di muka umum. Dalam film ini, penegasan atas Inpres tersebut diberlakukan atas larangan perayaan Imlek. Namun setelah reformasi, peraturan ini dicabut melalui Keppres No. 6/2000 di masa kepresidenan Abdurrahman Wahid dan diperkuat dengan Keppres No. 19/2002 di masa kepresidenan Megawati yang menjadikan Imlek sebagai hari raya nasional.

Regulasi tersebut muncul dalam film indie melalui visual dokumen-dokumen seperti pembedaan Kartu Tanda Penduduk (KTP), surat kewarganegaraan, dan surat ganti nama dari nama Tionghoa ke nama bernada Indonesia Regulasi lain yang tidak terkait dengan dokumen ditunjukkan dengan kalender yang tidak tercetak merah pada saat perayaan Imlek dilakukan. Kartu Tanda Penduduk (KTP) merupakan perangkat identitas individu yang bersifat dualisme bagi masyarakat Tionghoa. Perangkat tersebut mengambangkan konstruksi identitas itu sendiri. Kepatuhan masyarakat Tionghoa terhadap kebijakan pemerintah melalui Keppres Kabinet No. 127/U/ Kep/12/1966 tentang penggantian nama untuk Warga Negara Indonesia yang memakai nama Tionghoa menjadi hal yang dikontradiktif dengan perangkat identitas yang menegaskan ke-“tionghoa"-an mereka. Selain KTP, perangkat lain sebagai penanda identitas yang muncul sebagai alat diskriminasi adalah Surat Bukti Kewarganegaraan Republik Indonesia (SBKRI) yang hanya diperuntukkan bagi warga Tionghoa di Indonesia, tidak bagi warga Arab, India atau indo lainnya. 
Labelitas identitas Tionghoa yang diasimilasi menjadi bersifat keindonesiaan tidak sepenuhnya dilebur dengan adanya kartu identitas, Kartu Tanda Penduduk, yang diberi penanda khusus bagi warga negara keturunan. Hal tersebut mengonstruksi identitas secara mengambang. Konstruksi identitas menjadi bentuk konstruksi stimulus-respon atas kebijakan politik yang diterapkan pemerintah. Stimulus berupa sistem aturan peleburan yang pada penerapannya dilakukan tidak seutuhnya akan menghasilkan respon konstruksi identitas yang tidak seutuhnya atau identitas yang terbelah. Hal ini sejalan dengan pemikiran Bhabha (1994:1-2) yang menyatakan bahwa tidak ada budaya yang benar-benar murni sehingga selalu terbentuk ruang-antara. Budaya yang tidak benar-benar murni dan ruang-antara yang terbentuk dari budaya tersebut menyebabkan identitas yang terbentuk didalamnya juga tidak seutuhnya. Hal ini yang kemudian dikatakan bahwa identitas Tionghoa seperti halnya sekat imajiner yang mampu melewati atau menembus batas.

Ruang-antara tersebut muncul melalui tanda-tanda identitas baru melalui sudut pandang informal yaitu penanda budaya yang muncul dan bersifat mana suka (arbitrerness) seperti kolaborasi kesenian pawai pertunjukan Liong yang dikolaborasi dengan pertunjukan Sisingaan dari adat Sunda, angpau bergambar kartun Mickey Mouse yang notabene merupakan produk budaya Barat. Selain itu, penanda-penanda identitas juga muncul melalui benda-benda yang masih identik dengan budaya Tionghoa seperti jeruk Mandarin, berbagai atribut perayaan yang didominasi dengan warna merah dan kuning emas yang dipercaya sebagai warna keberuntungan dan kemakmuran.

Dalam konsep pemikiran individu, identitas dengan label nama menghasilkan suatu perluasan pemaknaan bahwa nama yang disematkan sebagai identitas diri juga bersifat mana suka. Label nama tidak sepenuhnya dianggap sebagai perwujudan jati diri melainkan pemenuhan sebagian kewajiban sebagai warga negara yang baik terkait munculnya Keppres Kabinet No 127/U/Kep/12/1966. Berdasarkan peraturan tersebut, orang Tionghoa mengambil nama Indonesia untuk disematkan sebagai nama diri hanya berdasarkan rasa suka, atau memiliki kemiripan dengan marga Tionghoanya seperti Han menjadi Handoko, Liem menjadi Halim, dan Loe menjadi Lukito. Konsepsi nama sebagai suatu doa yang biasanya masih dipegang oleh masyarakat Indonesia sehingga memiliki makna khusus tidak lagi dipentingkan. Nama Indonesia yang mereka pilih adalah nama yang mereka suka dan ingin mereka pakai sehingga seringkali nama Indonesia menjadi nama yang terdengar aneh oleh orang Indonesia sendiri seperti Nagawati atau Vaginawati.

Namun, tidak setiap aturan yang ditetapkan pemerintah juga dipatuhi oleh semua masyarakat Tionghoa. Representasi yang dimunculkan dalam film ini menunjukkan adanya bentuk negasi atas pemahaman nilai identitas yang dilembagakan melalui perlawanan atas aturan yang diterapkan sekaligus resistensi bagi unsur identitas leluhur yang dipertahankan. Berikut kutipan dari film SH yang menunjukkan pernyataan sikap atas regulasi yang ditetapkan pemerintah dalam representasi film indie.

Ayah Tan Ging Le:

'Temen Papah yang Tampubolon, gak pernah tuh ganti nama jadi Warsito atau Sungkono. Kenapa Papa harus ganti nama? Yaa akhirnya saya, adik dan kakak saya gak ada yang dikasi nama Indonesia...' 
Dari kutipan tersebut dapat diketahui bahwa konstruksi identitas dapat dibangun bukan hanya secara eksternal saja, namun dapat pula terkonstruksi secara internal oleh masyarakat Tionghoa itu sendiri. Konstruksi internal tersebut juga akan membangun korelasi dengan konstruksi eksternal. Korelasi tersebut dapat berupa afirmasi, negasi maupun variasi melalui perluasan atau penyempitan makna atas kontruksi identitas itu sendiri.

Refleksi lain yang berusaha digugat melalui film indie mengenai penanda identitas lainnya adalah larangan penggunaan bahasa Mandarin. Aku sebagai tokoh dalam ALUM menunjukkan dirinya bukan lagi keturunan Tionghoa tulen karena tidak lancar berbahasa Mandarin. Dalam hal ini, bahasa dianggap oleh sebagian orang Tionghoa itu sendiri sebagai penanda kemurnian darah orang Tionghoa di Indonesia. Ketidakmampuan ini tentu saja merupakan salah satu dampak dari dikeluarkannya Inpres No. 14/1967 yang juga memuat aturan pelarangan penggunaan bahasa Mandarin. Pelarangan penggunaan bahasa Mandarin di kalangan masyarakat Tionghoa yang seharusnya menjadikan bahasa Mandarin tersebut sebagai bahasa ibu menjadi penyebab turunnya tingkat kemampuan dan rendahnya angka pengguna bahasa tersebut sehingga berpengaruh terhadap keberlangsungan dan kelestarian dari bahasa itu sendiri. Berdasarkan tolok ukur penguasaan bahasa Mandarin menunjukkan adanya identitas terbelah yaitu menjadi Tionghoa tetapi tidak benar-benar Tionghoa.

\section{INDIE SEBAGAI JALUR PRODUKSI ALTERNATIF}

Jalur indie memiliki alur produksi yang berbeda dengan film mayor label yang tayang di bioskop sebagai salah satu target utamanya. Produksi indie yang menjadi wadah ekspresi bagi sineasnya berpijak dari wacana-wacana yang telah ada sebelumnya sehingga memunculkan ide dan menjadi pemikiran sineas untuk mewacanakan ulang dan mendekonstruksi wacana-wacana yang tidak sesuai dengan pemikirannya. Oleh karena itu, kebebasan ekspresi sineas menjadi utama dalam produksi film indie. Ekspresi sineas menjadi wacana baru yang muncul melalui proses produksi. Hal ini yang membedakan dengan wacana pada pemikiran Foucault. Foucault (2004:155-157) dalam arkeologi ilmu pengetahuan memisahkan objek dengan subjek. Dalam pemikirannya, wacana-wacana yang dibicarakan dan ditulis hanya terkait dengan praktik sehingga Foucault tertarik pada pernyataan-pernyataan yang terkait dengan sejarah. Dengan mengaitkan dengan sejarah akan diketahui mengenai terciptanya suatu wacana. Wacana yang muncul dalam hal ini tidak dikaitkan dengan subjek manusia sebagai pencipta karya sehingga Foucault menolak subjektivitas manusia atau pencipta karya. Wacana yang tercipta mengarah pada praktikpraktik yang ada pada masa, situasi atau kondisi tertentu. Praktik-praktik tersebut yang membentuk ilmu pengetahuan.

Sementara dalam proses produksi, tidak akan lepas dari unsur subjek pencipta karya. Dalam hal ini, sineas juga merupakan subjek yang menerima berbagai teks dari pembacaan berbagai konteks, baik dari cerapan karya, berbagai tulisan, pengalaman dan lain sebagainya. Sineas dalam memproduksi karya film tidak terlepas dari storage dari hasil pembacaan. Proses pemahaman terhadap teks menentukan posisi pembaca dalam teks tersebut. Menurut Iser (1987:111), posisi pembaca 
dalam teks terletak pada titik persimpangan antara ingatan dan harapan. Lebih jauh, Iser menjelaskan mengenai hubungan saling mempengaruhi antara ingatan dan harapan. Menurut Iser (1987:111), semua yang pernah dibaca akan mengendap di dasar ingatan pembaca. Selanjutnya, endapan tersebut akan masuk dalam konteks baru sehingga mengubah penyusunan kembali sintesis masa lalu yang kemudian dimunculkan kembali sebagai ingatan yang mengalami transformasi. Oleh karena itu, pembacaan wacana akan membangun tataran efek estetis yang menghasilkan restructuring pengalaman pembaca itu sendiri. Dengan demikian, terdapat keterkaitan antara objek dengan subjek, terutama apabila dikaitkan dengan proses produksi suatu karya.

Dalam produksi sebuah film, objek estetik dan subjek memiliki keterkaitan karena kemunculan film sebagai objek estetik berasal dari sineas yang mendasarkan kinerjanya dari observasi praktik-praktik yang mengendap dalam gudang memorinya dan kemudian direkonstruksi menjadi sebuah karya film. Hal ini sesuai dengan pernyataan Chatman (1980:27) sebagai berikut.

The aesthetic object, on the other hand, is that which comes into existence when the observer experiences the real object aesthetically. Thus, it is a construction (or reconstruction) in the observer's mind. Aesthetic objects may exist in the absence of a real object.

Dalam konteks sebuah produksi karya film, teori Foucault yang ingin memisahkan objek dan subjek serta lebih mengedepankan diskursif atas objek yang berdiri sendiri dengan aturan dan sistematikanya sehingga terlihat peta kontradiksi-kontradiksi di dalamnya yang menjadikan suatu diskursif hidup secara berkesinambungan melalui bangunan ruang- ruang perselisihan yang tidak melihat bahwa sistem yang terbangun dari suatu karya film sebagai suatu objek adalah sistem-sistem penanda semiotis dari ujaran yang dikeluarkan oleh sineas melalui scene-scene. Selain itu, ruang-ruang perselisihan yang diungkapkan Foucault tersebut harus merujuk pada subjeksubjek yang berselisih sehingga menimbulkan bangunan wacana. Dalam konteks bahasan ke-"tionghoa"-an, acuan sistem kuasa menjadi dasar penting yang harus diketahui. Melalui pijakan sistem kuasa tersebut menjadikan jalur indie menjadi jalur alternatif yang dapat dipergunakan untuk mengangkat tema-tema ke"tionghoa"-an.

Dengan melekatkan objek-subjek pada produksi film indie bertema ke-"tionghoa"an khususnya mengenai identitas Tionghoa, wacana yang mendeskripsikan diri sendiri akan lebih terlihat. Komparasi kontradiksikontradiksi yang terbangun atas wacana identitas ke-“tionghoa"-an akan muncul secara jelas atas dominasi subjek. Identitas yang muncul bukan hanya identitas yang dibentuk oleh kekuatan besar yang mendominasi, melainkan juga identitas yang berupaya disuarakan oleh kelompok terdominasi yang berupaya memposisikan dirinya. Seperti yang disampaikan Barker (2011:45) atas pembuat film Tionghoa di Indonesia yang keberadaannya lebih dilihat sebagai bukti dari 'ke-asing-an' daripada dilihat sebagai aset bangsa. Dalam hal ini, melalui proses produksi film yang mereka kerjakan, mereka berada dalam posisi untuk melokalisasi tren trans-lokal yang membantu subjek lokal untuk mengeksplorasi caracara baru dalam membayangkan diri mereka sendiri. Melalui paparan tersebut, Barker menyampaikan bahwa pembuat film Tionghoa seperti Wong Bersaudara maupun The 
Bersaudara mendudukkan diri sebagai perantara budaya dalam menciptakan kebudayaan nasional di atas layar. Dengan demikian, melalui produksi karya film yang mereka buat sesuai paparan konsep melokalisasi trans-lokal, pembuat film Tionghoa mendudukkan diri mereka sebagai Diri dan subjek lokal sebagai Liyan sehingga dengan melihat hasil produksi mereka, subjek lokal akan mendapatkan cara-cara baru dalam membayangkan diri mereka sendiri dan mengkonstruksi identitas sebagai masyarakat lokal. Dalam hal ini jelas terlihat bahwa produksi film yang dilakukan oleh subjek yang terdominasi dan senantiasa diposisikan sebagai objek yang dinilai akan memberikan posisi yang terbalik sebagai subjek yang menilai dan mewacanakan nilai atas pihak yang mendominasi. Melalui bentuk film yang eksperimental, tanda dan jejak tanda menjadi lebih luas untuk dibentuk dalam merepresentasikan gagasan dan membangun konstruksi berpikir tetapi dengan pemaknaan tanda yang lebih terbatas sehingga produksi film indie yang bergenre film eksperimental akan memungkinkan menjadi celah produksi alternatif untuk mengkonstruksi materi suatu objek mengikuti kehendak sineas dengan produksi tanda-tanda yang memiliki unsur makna yang lebih pasti karena batas-batas visual yang diberikan termasuk materi konstruksi identitas.

\section{SIMPULAN}

Identitas masyarakat Tionghoa di Indonesia dibentuk secara eksternal dan secara internal. Secara eksternal, identitas dibentuk oleh pandangan di luar masyarakat Tionghoa itu sendiri sedangkan secara internal, identitas dibentuk oleh masyarakat Tionghoa itu sendiri dalam memahami jati dirinya sebagai orang
Tionghoa. Selain itu, identitas ke-“tionghoa"an juga dipahami dengan pola formal dan informal. Secara pola formal, identitas dibentuk melalui peraturan pemerintah yang dibentuk secara sistemik. Sementara secara informal, identitas terbentuk dari konstruksi budaya yang bersifat mana suka (arbitrerness) berupa kolaborasi budaya yang pada akhirnya membentuk identitas baru yang tumbuh dari konteks ruang-antara masyarakat Tionghoa di Indonesia. Kemunculan identitas yang cair juga menjadi bentuk kemunculan entitas baru yang menggantikan karakteristik ke-"tionghoa"-an yang berkembang selama ini dan senantiasa diambangkan. Dengan demikian, penanda identitas masyarakat Tionghoa tidak selalu melekat secara identik dengan petandanya. Pemahaman masyarakat Tionghoa terhadap identitas diri tidak selalu identik dengan jati diri mereka. Bahkan pemahaman atas identitas diri mereka dapat dilakukan dengan pemaknaan secara meluas untuk memudahkan ruang gerak mereka di Indonesia.

\section{KEPUSTAKAAN}

Allen, P. 2003. "Contemporary Literature From The Chinese 'Diaspora' in Indonesia". Asian Ethnicity, pp. 383 - 401.

Andrew, D. 1984. Film in The Aura of Art. New Jersey: Princeton University Press.

Ang, I. 2001. On Not Speaking Chinese: Living Between Asia and The West. London and New York: Routledge.

Barker, C. S.-D. 2011. "Membayangkan Indonesia: Produser Etnis Tionghoa dan Sinema Pra-Kemerdekaan”. Dalam K. G. Barker, Mau Dibawa ke Mana Sinema Kita? Beberapa Wacana Seputar Film Indonesia. Jakarta: Salemba Humanika. Bhabha, Homi K. 1994. The Location of Culture. London and New York: Routledge.

Bordwell, D. \& Kristin Thompson. 2001. Film Art: An Introduction. New York: Mc Grow Hill. 
Burke, P. J. \& J. E. Stets. 2009. Identity Theory. New York: Oxford University Press.

Chatman, S. 1980. Story and Discourse: Narrative Structure in Fiction and Film. Ithaca and London: Cornell University Press.

Creswell, J. 2012. Research Design: Pendekatan Kualitatif, Kuantitatif, dan Mixed. Yogyakarta: Pustaka Pelajar.

Danesi, M. 2010. Pengantar Memahami Semiotika Media. Yogyakarta: Jalasutra.

Eagleton, T. 1978. Criticism and Ideology: A Study in Marxis Literary Theory. London: Verso.

Eagleton, T. 2006. Marxism and Literary Criticism. London: Routledge.

Foucault, M. 2004. Archaeology of Knowledge. London: Routledge.

Hardiman, F. B. 2015. Seni Memahami: Hermeneutik dari Schleiermacher sampai Derrida. Yogyakarta: Kanisius.

Hatta, M. 1988. Warga Negara Indonesia Turunan Tionghoa. In: R. Saidi, ed. Baba Bisa Menjadi Indonesier: Bung Hatta, Liem Koen Hian, dan Sindhunatha Menyorot Masalah Tionghoa di Indonesia. Jakarta: Lembaga Pengkajian Masalah Pembauran.

Heryanto, A. 1997. Silence in Indonesian Literary Discourse. SOJOURN, pp. 26 $-45$.

Hoon, C.-Y. 2012. Identitas Tionghoa Pasca Suharto: Budaya, Politik dan Media. Jakarta: LP3ES dan Yayasan Nabil.

Iser, W. 1987. The Act of Reading: Theory of Aesthetic Response. London: The Johns Hopkins Press Ltd.

Joesoef, D. 1996. "Sistem Sosial Budaya dan Pengaruhnya Terhadap Bisnis Tionghoa". Dalam: Etika Bisnis Tionghoa: Suatu Kajian terhadap Perekonomian di Indonesia. Jakarta: Gramedia Pustaka Utama.

Junaedi, F., $2009 . \quad$ [Online] Available at: http://www.umy.ac.id/ fakultas-ilmu-sosial-ilmu-politik/wpcontent/uploads/2010/04/MembacaIndonesia-dari-Film-dan-SinemaIndonesia.pdf, Junaedi, F., 2009. [Online] Available at: http://www.umy.ac.id/ fakultas-ilmu-sosial-ilmu-politik/wp-
content/uploads/2010/04/MembacaIndonesia-dari-Film-dan-SinemaIndonesia.pdf, [Diakses 3 Oktober 2013].

Kustedja, S. 2012. "Jejak Komunitas Tionghoa dan Perkembangan Kota Bandung". Jurnal Sosioteknologi, 11 Agustus. pp. 105-128.

Lohanda, M. 2002. Growing Pain: The Chinese and The Dutch in Colonial Java, 1890 - 1942 . Jakarta: Yayasan Cipta Loka Caraka.

Mahfud, C. 2013. Manifesto Politik Tionghoa di Indonesia. Yogyakarta: Pustaka Pelajar.

Prakoso, G. 2006. Kamera Subyektif Rekaman Perjalanan dari Sinema Ngamen ke Art Cinema. Jakarta: Dewan Kesenian Jakarta dan Yayasan Seni Visual Indonesia.

Setijadi, C. 2013. "Chinese, Belonging and Cosmopolitan Subjectivities in Post Suharto Independent Films". Dalam: Chinese Indonesians Reassessed History Religion and Belonging. London and New York: Routledge. pp. 65-82.

Suryadinata, L. 1984. Dilema Minoritas Tionghoa. Jakarta: Grafiti Pers. 